\title{
Cellular and molecular evidence for a role of tumor necrosis factor alpha in the ovulatory mechanism of trout
}

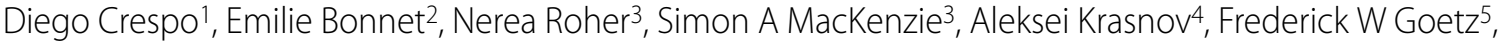 \\ Julien Bobe ${ }^{2}$ and Josep V Planas*1
}

\begin{abstract}
Background: The relevance of immune-endocrine interactions to the regulation of ovarian function in teleosts is virtually unexplored. As part of the innate immune response during infection, a number of cytokines such as tumor necrosis factor alpha (TNF alpha) and other immune factors, are produced and act on the reproductive system. However, TNF alpha is also an important physiological player in the ovulatory process in mammals. In the present study, we have examined for the first time the effects of TNF alpha in vitro in preovulatory ovarian follicles of a teleost fish, the brown trout (Salmo trutta).

Methods: To determine the in vivo regulation of TNF alpha expression in the ovary, preovulatory brook trout (Salvelinus fontinalis) were injected intraperitoneally with either saline or bacterial lipopolysaccharide (LPS). In control and recombinant trout TNF alpha (rtTNF alpha)-treated brown trout granulosa cells, we examined the percentage of apoptosis by flow cytometry analysis and cell viability by propidium iodide (PI) staining. Furthermore, we determined the in vitro effects of rtTNF alpha on follicle contraction and testosterone production in preovulatory brown trout ovarian follicles. In addition, we analyzed the gene expression profiles of control and rtTNF alpha-treated ovarian tissue by microarray and real-time PCR (qPCR) analyses.

Results: LPS administration in vivo causes a significant induction of the ovarian expression of TNF alpha. Treatment with rtTNF alpha induces granulosa cell apoptosis, decreases granulosa cell viability and stimulates the expression of genes known to be involved in the normal ovulatory process in trout. In addition, rtTNF alpha causes a significant increase in follicle contraction and testosterone production. Also, using a salmonid-specific microarray platform (SFA2.0 immunochip) we observed that rtTNF alpha induces the expression of genes known to be involved in inflammation, proteolysis and tissue remodeling. Furthermore, the expression of kallikrein, TOP-2, serine protease 23 and ADAM 22, genes that have been postulated to be involved in proteolytic and tissue remodeling processes during ovulation in trout, increases in follicles incubated in the presence of rtTNF alpha.

Conclusions: In view of these results, we propose that TNF alpha could have an important role in the biomechanics of follicle weakening, ovarian rupture and oocyte expulsion during ovulation in trout, primarily through its stimulation of follicular cell apoptosis and the expression of genes involved in follicle wall proteolysis and contraction.
\end{abstract}

\section{Background}

Fish are exposed to a variety of pathogens and stressful conditions which may cause severe reproductive consequences $[1,2]$. It is now known that activation of the

* Correspondence: jplanas@ub.edu

${ }^{1}$ Departament de Fisiologia, Facultat de Biologia, Universitat de Barcelona and Institut de Biomedicina de la Universitat de Barcelona (IBUB), 08028 Barcelona, Spain

Full list of author information is available at the end of the article immune system as a result of a bacterial infection is characterized by the production of a wide variety of immune factors, including pro-inflammatory cytokines and chemokines [3] which can act as local chemical modulators or be secreted into the circulation and act as hormones. In particular, exposure to lipopolysaccharide (LPS), an active component of the wall of Gram-negative bacteria, induces the expression of TNF $\alpha$ in trout mac- 
rophages [4]. Once secreted into the circulation, the pleiotropic cytokine TNF $\alpha$ can then act on a number of different tissues, including non-immune tissues.

In mammals, TNF $\alpha$ is known to act in the ovary, where it affects differentiation, proliferation, steroid production, inflammation and induction of apoptosis through specific receptors [5-7]. Interestingly, TNF $\alpha$ is considered to be a mediator of ovulation through its stimulatory role on follicular apoptosis and breakdown of the extracellular matrix (ECM) in the follicle wall $[8,9]$. Therefore, in addition to its local production and action, TNF $\alpha$ can act as a mediator signaling the status of the immune system to the reproductive system. In fish, very little is known about the interaction between the immune and the reproductive systems and, in particular, of the involvement of TNF $\alpha$ in the reproductive process. We have previously reported that LPS administration results in the induction of apoptosis in the trout ovary and that preovulatory trout follicles incubated with conditioned medium from LPS-stimulated trout macrophages showed an increase in follicle contraction, suggesting that factors produced by trout macrophages in response to LPS may stimulate follicle contraction [10]. In view of these observations, we hypothesize that TNF $\alpha$ could be one of the most likely mediators of the effects of LPS in the trout ovary. Therefore, it is important to address the issue of the impact of the activation of the immune response by TNF $\alpha$ on reproductive function in fish.

In the present study, we have examined the effects (in vitro) of recombinant trout TNF $\alpha$ (rtTNF $\alpha)$ on the reproductive function of preovulatory brown trout (Salmo trutta) at various levels: (1) ovarian apoptosis and granulosa cell viability, (2) follicle contraction and steroid production and (3) gene expression profiles (microarray and qPCR analyses).

\section{Methods}

\section{Animals}

Reproductively mature female brown trout (Salmo trutta) from a cultured stock at the Piscifactoria de Bagà (Generalitat de Catalunya, Bagà, Spain) were kept under natural conditions of temperature and photoperiod. Fish at the preovulatory stage (according to the position of the germinal vesicle (GV) in oocytes that were cleared using a solution previously described [11]), were anesthesized in 3 -aminobenzoic acid ethyl ester ( $0.1 \mathrm{~g} / \mathrm{l}$; Sigma, Alcobendas, Spain) dissolved in fresh water, and the fish were sacrificed by concussion prior to the collection of the ovaries. The dissected ovaries were immediately used for the various in vitro assays. For the experiment on the in vivo regulation of TNF $\alpha$ expression in the ovary, preovulatory brook trout (Salvelinus fontinalis) were briefly anesthesized in 3-aminobenzoic acid ethyl ester $(0.1 \mathrm{~g} / \mathrm{l})$ and injected intraperitoneally with either saline $(\mathrm{n}=3)$ or
E. coli lipopolysaccharide (LPS) (3 mg/kg weight; Sigma) $(\mathrm{n}=3)$ once a day over four consecutive days, as previously reported [10]. Twenty four hours after the last injection, fish were anesthesized (as described above) and sacrificed by spinal transection prior to the collection of the ovaries. Ovarian tissue (previously de-yolked by gentle pressure) was flash frozen in liquid nitrogen and stored at $-80^{\circ} \mathrm{C}$, until RNA isolation.

\section{Hormones and reagents}

Coho salmon (Oncorhynchus kisutch) luteinizing hormone (sLH) was a kind gift from Dr. Penny Swanson (National Marine Fisheries Service, Seattle, WA) [12] and was dissolved directly in incubation medium.

For the generation of rtTNF $\alpha$, the mature form of TNF $\alpha$ from brook trout (Salvelinus fontinalis) was subcloned into an expression vector, produced in E. coli, refolded, concentrated and shown to be biologically active using a fish cell line [13].

\section{Ovarian tissue incubations}

After dissection, brown trout preovulatory ovaries were placed in Hank's balanced salt solution (HBSS) and individual ovarian follicles were manually separated with forceps from each ovary on ice, as previously described [14]. For the follicle contraction experiments, brown trout preovulatory follicles punctured using a 25-gauge hypodermic needle were incubated in HBSS containing $0.2 \%$ BSA (fraction V, Sigma; HBSS-BSA) in $6 \mathrm{~cm}$ culture dishes (10 follicles $/ 4 \mathrm{ml}$ ) in the presence of the test compounds for $16 \mathrm{~h}$ at $15^{\circ} \mathrm{C}$ under shaking conditions (100 rpm). Follicle contraction was determined by measuring the weight of the 10 follicles in each replicate after incubation, as previously described and validated for epinephrine stimulation $[15,16]$. Since contraction results in the expulsion of yolk through the puncture site, a decrease in follicle weight indicates an increase in follicle contraction. For in vitro steroid production experiments, intact preovulatory brown trout follicles were incubated (10 follicles/well/1 $\mathrm{ml}$ ) in HBSS-BSA in 24-well culture plates, in the absence or presence of different test compounds for $24 \mathrm{~h}$ at $15^{\circ} \mathrm{C}$ with gentle shaking $(100 \mathrm{rpm})$. At the termination of the incubation, the medium was removed and stored at $20^{\circ} \mathrm{C}$, until assayed.

To collect ovarian tissue for RNA extraction, preovulatory follicles from each of a total of three females were incubated (400 follicles $/ 50 \mathrm{ml}$ ) in HBSS-BSA in the absence or presence of $\mathrm{rtTNF} \alpha(100 \mathrm{ng} / \mathrm{ml}$, dissolved directly in HBSS-BSA), at $15^{\circ} \mathrm{C}$ for $24 \mathrm{~h}$ with gentle shaking $(100 \mathrm{rpm})$. At the end of the incubation follicles (previously de-yolked by gentle pressure) were removed, flash frozen in liquid nitrogen and stored at $-80^{\circ} \mathrm{C}$ until assayed. 


\section{Steroid radioimmunoassay}

The concentration of testosterone $(\mathrm{T})$ in brown trout ovarian follicle incubates were measured directly using commercial radioimmunoassay (Schering-CIS, Madrid, Spain), as described previously $[17,18]$.

\section{Analysis of apoptosis and cell viability}

Granulosa cell viability was assessed by incubating brown trout ovarian follicles in the absence or presence of 100 $\mathrm{ng} / \mathrm{ml} \mathrm{rtTNF} \alpha$ for $18 \mathrm{~h}$ at $15^{\circ} \mathrm{C}$, separating the granulosa layers and staining them with propidium iodide (PI; 50 $\mu \mathrm{g} / \mathrm{ml}$; Sigma). Subsequently, sheets of granulosa layers were mounted onto glass slides, counterstained with DAPI and visualized under a fluorescent microscope. To determine the incidence of apoptosis after rtTNFo treatment, granulosa cells were obtained from granulosa layers (isolated from control and rtTNF $\alpha$-treated follicles) by enzymatic digestion with $0.2 \%$ collagenase type IA (Clostridium histolyticum; Sigma) under gentle agitation for $2 \mathrm{~h}$ at room temperature. After incubation, the homogenate was filtered through a $100 \mu \mathrm{m}$ filter and subsequently through a $40 \mu \mathrm{m}$ filter before centrifugation for 6 min at $500 \mathrm{~g}$. The pellet was washed with $0.5 \mathrm{ml} 1 \times$ PBS and centrifuged $5 \mathrm{~min}$ at $500 \mathrm{~g}$. Isolated granulosa cells were resuspended in $70 \%$ ethanol and stored at $-20^{\circ} \mathrm{C}$ until use. To analyze the incidence of apoptosis, granulosa cells were resuspended in PI staining buffer $(20 \mu \mathrm{g} /$ $\mathrm{ml}$ PI, 0.1\% Triton X-100, $200 \mu \mathrm{g} / \mathrm{ml}$ RNase A; Sigma) prior to analysis by flow cytometry (FACS analysis).

\section{RNA isolation and CDNA synthesis}

Total RNA from ovarian tissue was isolated using TRIzol Reagent (Invitrogen, Barcelona, Spain), following the manufacturer's instructions and guidelines. Quantification was carried out with Qubit fluorometer (Invitrogen). cDNA synthesis was performed on 5 ìg DNase-treated (RQ1 DNase, Promega, Barcelona, Spain) total RNA using SuperScript III Transcriptase (Invitrogen), oligo(dT) primer and random hexamer primers (Promega), according to the manufacturer's protocols. The RNA was stored at $-80^{\circ} \mathrm{C}$ until use.

\section{Microarray analyses}

Microarray analyses were performed using the salmonid fish cDNA microarray platform (SFA2.0 immunochip) previously validated and described $[19,20]$ that has been deposited in GEO under accession number GPL6154. Total RNA from pooled control and TNF $\alpha$-treated brown trout preovulatory follicles $(n=20)$ from each of a total of three females was labelled with Cy3-dUTP and Cy5dUTP (GE Healthcare, Barcelona, Spain) using SuperScript III Transcriptase. The cDNA synthesis reaction was performed at $50^{\circ} \mathrm{C}$ for $2 \mathrm{~h}$ in a $20 \mu \mathrm{l}$ reaction volume, followed with RNA degradation with $0.2 \mathrm{M} \mathrm{NaOH}$ at $37^{\circ} \mathrm{C}$ for $15 \mathrm{~min}$ and alkaline neutralization with $0.6 \mathrm{M}$
Hepes. Labeled cDNA was purified with Microcon YM30 (Millipore, Madrid, Spain). We used a dye swap experimental design and each pooled sample (20 follicles) from each female was hybridized to two microarrays. For the first slide, pooled test and control cDNA were labeled with $\mathrm{Cy} 5$ and $\mathrm{Cy} 3$ respectively, and for the second array dye assignment was reversed. The slides were pretreated with $1 \%$ BSA (fraction V), $5 \times$ SSC, $0.1 \%$ SDS (30 min at $\left.50^{\circ} \mathrm{C}\right)$ and washed with $2 \times \operatorname{SSC}(3 \mathrm{~min})$ and $0.2 \times \operatorname{SSC}(3$ $\mathrm{min}$ ) at room temperature and hybridized overnight at $60^{\circ} \mathrm{C}$ in a cocktail containing $1.3 \times$ Denhardt's, $3 \times$ SSC, $0.3 \% \mathrm{SDS}, 2.1 \mu \mathrm{g} / \mu \mathrm{l}$ polyadenylate and $1 \mu \mathrm{g} / \mu \mathrm{l}$ yeast tRNA. All chemicals were from Sigma. After hybridization, slides were washed at room temperature in $0.5 \times$ SSC and $0.1 \%$ SDS for $15 \mathrm{~min}, 0.5 \times$ SSC and $0.01 \%$ SDS for $15 \mathrm{~min}$, and twice in $0.06 \times \mathrm{SSC}$ for 2 and $1 \mathrm{~min}$, respectively. Scanning was performed with ScanArray 5000 (GSI Lumonics) and images were processed with GenePix Pro 5.0 (Axon). The measurements in spots were filtered by criteria $I / B \geq 3$ and $(I-B) /\left(S_{I}+S_{B}\right) \geq 0.6$, where $I$ and $B$ are the mean signal and background intensities and $S_{I}, S_{B}$ are the standard deviations. After subtraction of median background from median signal intensities, the expression ratios (ER) were calculated. Locally weighted non-linear regression (Lowess) normalization was performed, first for the whole slide and next for twelve rows and four columns per slide. The differential expression was assessed by the difference of the mean $\log _{2}$ ER from zero between the slides with reverse labelling (6 spot replicates per gene on each slide, Student's ttest, $\mathrm{p}<0.01)$. The $\log _{2}$ ER ranked up- or down-regulated genes were analyzed interrogating the functional classes of Gene Ontology (GO) [21] and compared by the sums of ranked genes (Student's t-test, $\mathrm{p}<0.05$ ). Complete microarray results were submitted to NCBI GEO Omnibus (GSE20296).

\section{Quantitative real-time PCR (qPCR)}

In order to quantify mRNA expression of individual genes, quantitative real-time PCR (qPCR) was carried out with the same samples used for microarray analyses (pooled follicles from each of three separate females). cDNA was diluted 1:25 for target mRNA and 1:2000 for $18 \mathrm{~S}$ and used as a template. The reactions $(20 \mu \mathrm{l}$ final volume) contained $10 \mu \mathrm{l}$ of SYBR GreenER qPCR SuperMix (Invitrogen), $500 \mathrm{nM}$ concentration of forward and reverse primers and $5 \mu \mathrm{l}$ of cDNA. Reactions were run in a iCycler Thermal Cycler (BioRad, Alcobendas, Spain) under the following protocol: $2 \mathrm{~min}$ at $50^{\circ} \mathrm{C}, 8 \mathrm{~min}$ at $95^{\circ} \mathrm{C}$, followed by 40 cycles of $15 \mathrm{sec}$ denaturation at $95^{\circ} \mathrm{C}$ and $30 \mathrm{sec}$ at $60^{\circ} \mathrm{C}$, and a final melting curve of 81 cycles from $55^{\circ} \mathrm{C}$ to $95^{\circ} \mathrm{C}\left(0.5^{\circ} \mathrm{C}\right.$ increments every $\left.10 \mathrm{sec}\right)$. All samples were run in triplicate and fluorescence was measured at the end of every extension step. Fluorescence 
readings were used to estimate the values for the threshold cycles $(C t)$. Relative expression of mRNA was evaluated by $-\Delta \Delta C \mathrm{t}$, based on the quantification method by Livak and Schmittgen [22]. As the reference gene, 18S ribosomal RNA was selected. For all primer pairs, a dilution curve obtained from a serially diluted ovarian cDNA pool was used to ensure that PCR efficiency was higher than $90 \%$. Primer sequences, amplicon sizes and GenBank accession numbers of the target genes are presented in Table 1.

\section{Statistical analysis}

Differences among groups were analyzed for statistical significance with non parametric Mann-Whitney U test or by one-way analysis of variance (ANOVA) followed by the Fisher protected least significant different test, using StatView 5.0 (SAS Institute, Cary, NC). Results are expressed as means $\pm \mathrm{SE}$ and differences between groups were considered to be significant if $\mathrm{p}<0.05$.

\section{Results}

In a previous study, we reported changes in ovarian function in trout that had been administered with LPS to simulate a bacterial infection [10]. Specifically, we hypothesized that the induction of follicular apoptosis in LPS-injected females and the stimulation of follicle contraction by LPS-stimulated macrophage conditioned medium could have been caused by the increased local production of pro-apoptotic cytokines, such as TNF $\alpha$. Therefore, in order to determine if TNF $\alpha$ could mediate the observed effects of LPS in the trout ovary, in the present study we investigated the direct biological effects of rtTNF $\alpha$ on trout preovulatory follicles. Importantly, we first demonstrate here that LPS administration in vivo causes a significant induction $(1.99$-fold; $\mathrm{p}<0.05)$ of the

Table 1: Sequences of primers used in gene expression analyses by qPCR

\begin{tabular}{|c|c|c|c|}
\hline Clone ID & Clone name & Primer sequence (5'-3') & Amplicon size (bp) \\
\hline AJ278085 & Tumor necrosis factor alpha (TNFa) & $\begin{array}{l}\text { (F) AGCATGGAAGACCGTCAA } \\
\text { (R) TTCGTTTACAGCCAGGCT }\end{array}$ & 271 \\
\hline CA344136 & Small inducible cytokine B14 precursor & $\begin{array}{l}\text { (F) AGCTGAAGCCTACAAGTGCAGGTGC } \\
\text { (R) TCCTTCCAGATCCGGAACCAC }\end{array}$ & 219 \\
\hline CU068239 & Leukocyte cell-derived chemotaxin 2 & $\begin{array}{l}\text { (F) AGGACACCACGGCGCAAGCAGAG } \\
\text { (R) TGTCACACATCTGGACGTGGACG }\end{array}$ & 314 \\
\hline CA374135 & $\mathrm{CCL} 4$ & $\begin{array}{l}\text { (F) TGCTTGTTCTGGTACTCAGTGCCA } \\
\text { (R) TGTCTGAGGACCTGGCACACACC }\end{array}$ & 207 \\
\hline CA351440 & TNF decoy receptor & $\begin{array}{l}\text { (F) TCTCCTGGTATTGGCGCTCTGTGGT } \\
\text { (R) TATAAGTCGGTGTGTGAGCGCCTGA }\end{array}$ & 65 \\
\hline DW550559 & Coronin-1C & $\begin{array}{l}\text { (F) AGTGGTGCGAGCGAGTAAGT } \\
\text { (R) GACAGGTCCCGTATGACCAC }\end{array}$ & 241 \\
\hline CU067298 & Triosephosphate isomerase & $\begin{array}{l}\text { (F) GCTTCCTTGTGGGTGGTGCTTC } \\
\text { (R) CCACAGGAAGGAGCAGATGACACC }\end{array}$ & 181 \\
\hline CU069718 & Serine protease-like protein-1 & $\begin{array}{l}\text { (F) ACCAAAAACATGCTGTGTGC } \\
\text { (R) CCCTCCATTTGAAGTGATCC }\end{array}$ & 111 \\
\hline CA364711 & Inhibitor of apoptosis protein 3 & $\begin{array}{l}\text { (F) TGCTTCTGCTGTGGAGGGATG } \\
\text { (R) CGTGGTCAATAGGGTGCTGGA }\end{array}$ & 244 \\
\hline AF005026 & Kallikrein (KT-14) & $\begin{array}{l}\text { (F) CCAGGAGGTGGAATTAGGATGAGA } \\
\text { (R) GCAGAGCAGCAGTCAGGAACA }\end{array}$ & 167 \\
\hline AF223388 & Novel osteopontin-like protein (NOP) & $\begin{array}{l}\text { (F) CAGCAGAGAGCAACGAGAGCCAT } \\
\text { (R) AGGGTCATAGAGCACCTTCCAGG }\end{array}$ & 182 \\
\hline U67854 & Trout ovulatory protein-2 (TOP-2) & $\begin{array}{l}\text { (F) GGGATGTGTGCGGAGTTATGCT } \\
\text { (R) ACTGTGTCGGTGCAATGCAGTCAT }\end{array}$ & 99 \\
\hline AF156738 & Trout decoy receptor (TDcR) & $\begin{array}{l}\text { (F) GCGTCGGTTAGCAATGAGGC } \\
\text { (R) GGTTCTTGCCTCCCTCTTGTG }\end{array}$ & 45 \\
\hline CA380218 & $\begin{array}{l}\text { Macrophage migration inhibitory factor } \\
\text { (MIF) }\end{array}$ & $\begin{array}{l}\text { (F) AGGCAACAGATGAACTGGCCAAGG } \\
\text { (R) AGGCCACATTCGCTGCCTCCA }\end{array}$ & 258 \\
\hline AF308735 & $18 \mathrm{~S}$ ribosomal RNA & $\begin{array}{l}\text { (F) CGGAGGTTCGAAGACGATCA } \\
\text { (R) TCGCTAGTTGGCATCGTTIAT }\end{array}$ & 62 \\
\hline
\end{tabular}




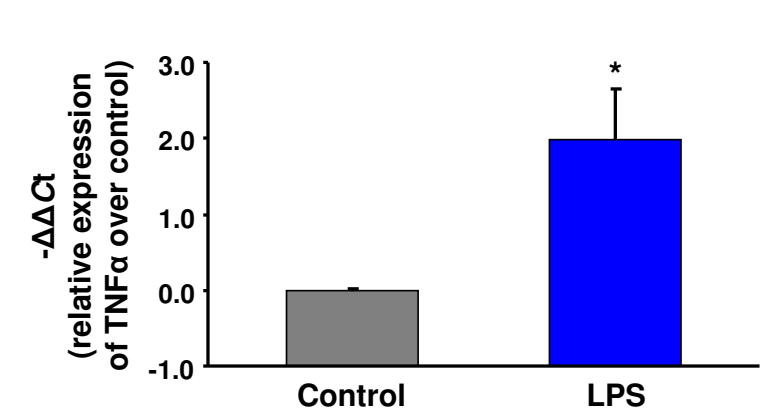

Figure 1 Expression of tumor necrosis factor $a(T N F a)$ in the brook trout ovary in response to lipopolysaccharide (LPS) administration in vivo. The relative expression of TNFa was determined by real-time PCR (qPCR) and normalized to the abundance of 185 . The results from ovarian tissue from 3 separate brook trout females for each group are expressed as mean $-\Delta \Delta C t \pm S E(n=3)$ with respect to the control, which has been set at 0 . Statistically significant $(p<0.05)$ differences with respect to the control group are indicated by an asterisk $(*)$.

ovarian expression of TNF $\alpha$ in brook trout (Fig. 1), the species used in our previous study (8). We have also confirmed the stimulation of ovarian TNF $\alpha$ expression by LPS administration in rainbow trout (results not shown), which suggest that this effect may not be species-specific.

\section{Effects of rtTNFa on ovarian apoptosis and viability}

We investigated whether rtTNF $\alpha$ can induce apoptosis and/or cause a decrease in the viability of trout granulosa cells. Our results clearly show that the incidence of apoptotic granulosa cells significantly $(\mathrm{p}<0.05)$ increased in trout ovarian follicles incubated with rtTNF $\alpha$ (Fig. 2A). Evaluation of granulosa cell viability by PI staining provided additional evidence that exposure of trout ovarian follicles to rtTNFo in vitro causes a marked decrease in granulosa cell viability (Fig. 2B). In contrast to the untreated controls in which almost no PI-positive cells were detected (Fig. 2B), treatment with rtTNF $\alpha$ increased the presence of PI-positive cells (Fig. 2B). Exposure of granulosa cells to $1 \%$ paraformaldehyde (PFA), used as a positive control, also caused a decrease in cell viability (Fig. 2B).

\section{Effects of rtTNFa on follicle contraction}

Follicle contraction was significantly $(\mathrm{p}<0.05)$ stimulated in isolated trout preovulatory follicles incubated in the presence of rtTNF $\alpha$ (Fig. 3), as evidenced by the decrease in follicle weight when compared with untreated unpunctured controls (UP controls) and punctured controls ( $\mathrm{P}$ controls). Epinephrine $(10 \mu \mathrm{M})$, used as a positive control, also significantly $(\mathrm{p}<0.05)$ stimulated follicle contraction. There was approximately a $12 \%$ spontaneous contraction in punctured control follicles, as shown in previous studies $[15,16]$.

\section{Effects of rtTNFa on steroid production}

Incubation with rtTNF $\alpha$ stimulated the in vitro production of $\mathrm{T}$ in a concentration-dependent manner (significantly at 10 and $50 \mathrm{ng} / \mathrm{ml} ; \mathrm{p}<0.05)($ Fig. $4 \mathrm{~A}$ ) by intact trout follicles. As expected, $\mathrm{sLH}(25 \mathrm{ng} / \mathrm{ml})$ significantly $(\mathrm{p}<0.05)$ stimulated the production of $\mathrm{T}$. In the same manner, rtTNF $\alpha$ caused a significant $(\mathrm{p}<0.05)$ potentiation of the effects of sLH on T production (Fig. 4B).

\section{Effects of rtTNFa on ovarian gene expression}

In order to evaluate the effects of rtTNF $\alpha$ treatment on gene expression in the trout ovary, we used a salmonid fish cDNA microarray platform (SFA2.0) enriched with immune-related genes that has been previously validated for studies involving response to stress and toxicity $[19,20]$ as well as the immune response in trout $[10,23-$ 25].

Overall, a larger number of genes were up-regulated $(\mathrm{n}=$ $235)$ rather than down-regulated $(n=158)$ in trout ovarian follicles in response to rtTNF $\alpha$ treatment (Fig. 5 and Additional File 1, Figure S1). However, applying a cut-off value of $>1 \log _{2}$ ER (expression ratio) over the differentially expressed genes (DEGs) $(\mathrm{p}<0.01)$ resulted in a considerably higher number of genes being down-regulated $(n=28)$ as opposed to those up-regulated $(n=6)$ (Fig. 5). Furthermore, the highest ERs in individual genes were observed among the down-regulated genes (Additional File 1, Figure S1). Fig. 6 shows examples of DEGs with known functions based on gene ontology.

The DEGs that were identified in response to rtTNF $\alpha$ treatment in the trout ovary were analyzed by interrogating the functional classes of Gene Ontology (GO) [21] and compared by the mean $\log _{2}$ ER of ranked genes (Student's t-test, $\mathrm{p}<0.05$ ) (Fig. 7 and Additional File 2, Figure $\mathrm{S} 2 \mathrm{~A}$ and $\mathrm{B})$. The categories G1/S transition of mitotic cell cycle, nucleotide metabolism, DNA replication and mitotic cell cycle were reduced by rtTNF $\alpha$, whereas protein biosynthesis and structural constituent of ribosome were enhanced. Also, categories related to protein kinase and I-kappaB kinase NF-kappaB cascades and apoptosis were up-regulated. Furthermore, categories involved in tissue remodeling, cytoskeleton and muscle contraction were also increased.

Microarray analyses showed that several genes involved in apoptosis underwent changes in response to rtTNF $\alpha$ in vitro administration (Fig. 6), in support of the observed increase in apoptosis in rtTNF $\alpha$-treated ovarian follicles (Fig. 2). Receptor-interacting serine/threonine-protein kinase 2 (cell death protein RIP) and growth arrest and DNA-damage inducible GADD45 beta, involved in TNF $\alpha$-induced apoptosis, were significantly up-regulated. TNF-dependent genes increased their expression, including several receptors (TNF receptor superfamily members). Also, inhibitor of apoptosis protein 3 and cdk 


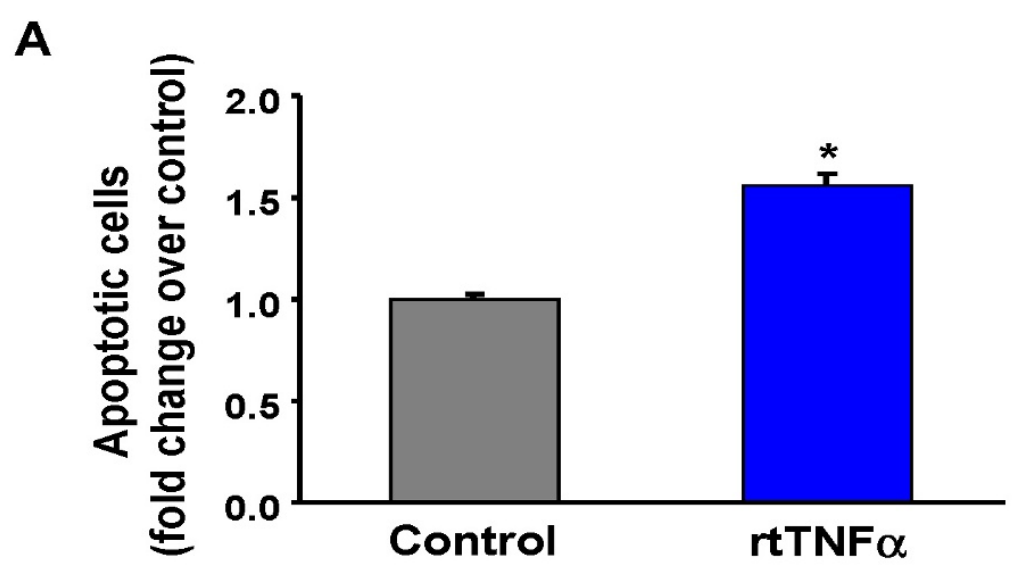

B

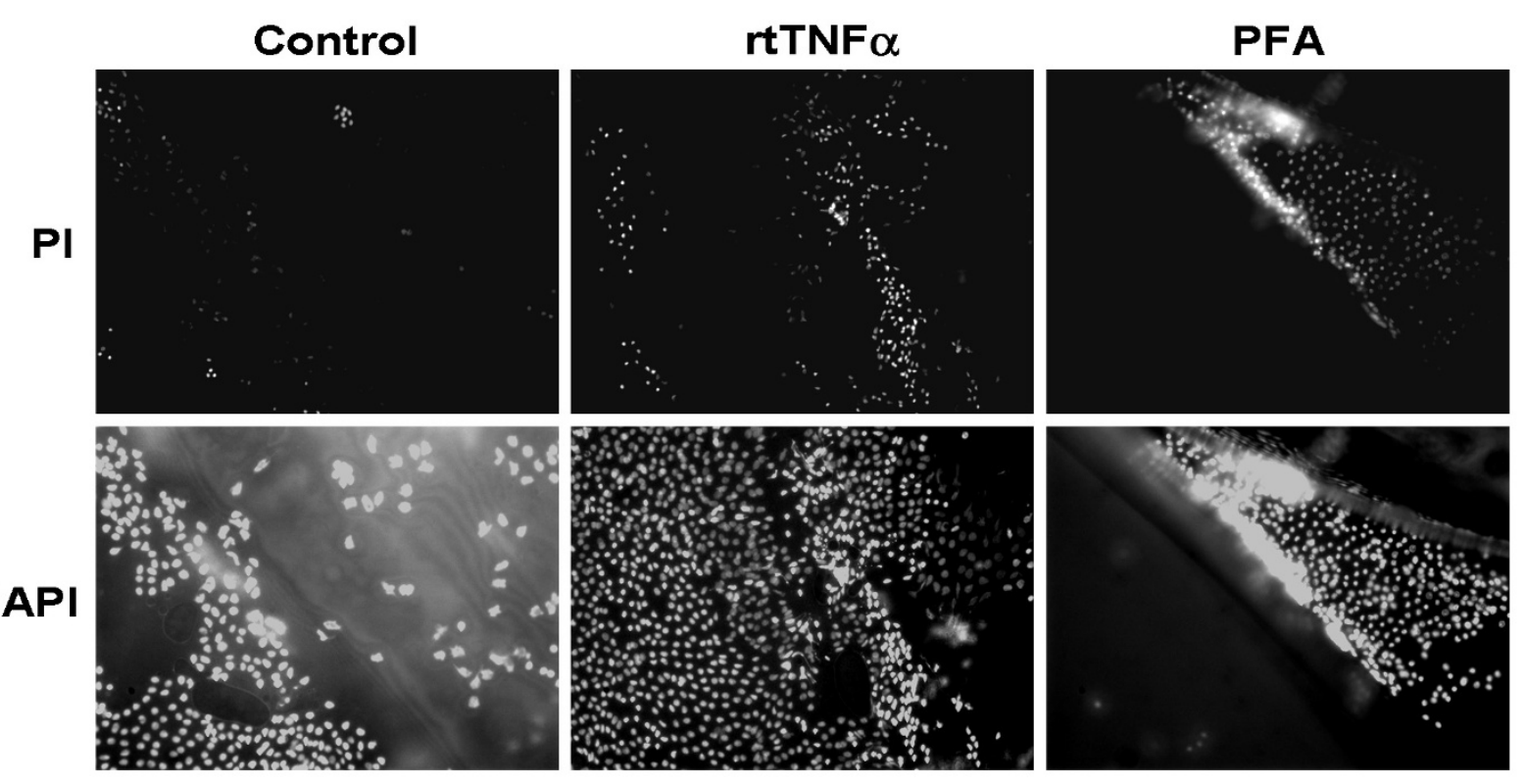

Figure 2 Effects of rtTNFa treatment in vitro on apoptosis and cell viability in brown trout preovulatory follicles. A. To determine the incidence of apoptosis, granulosa cells isolated from trout preovulatory follicles incubated in the absence or presence of rtTNFa (100 ng/ml) were stained with propidium iodide (PI) and analyzed by flow cytometry (FACS analysis). Each bar represents the mean $\pm \mathrm{SE}$ of six independent experiments, each performed with ovarian tissue from a different female $(n=6)$. The results are expressed with respect to the control group which has been set at 1 . Statistically significant $(p<0.05)$ differences with respect to the control group are indicated by an asterisk $(*)$. B. Granulosa cell viability was assessed by incubating brown trout preovulatory follicles in the absence or presence of $100 \mathrm{ng} / \mathrm{ml}$ rtTNFa, or $1 \%$ paraformaldehyde (PFA) as a positive control, for $18 \mathrm{~h}$ at $15^{\circ} \mathrm{C}$, separating the granulosa layers and staining them with PI. Subsequently, sheets of granulosa layers were mounted onto glass slides, counterstained with DAPI and visualized under a fluorescent microscope.

inhibitor p21 binding protein were significantly downregulated after rtTNF $\alpha$ treatment. In addition, the expression of telomerase reverse transcriptase and nuclear matrix protein NMP200 were also reduced in the trout ovary. In mammals, loss of expression of these two genes results in apoptosis and decreased cell survival after DNA damage [26,27]. Interestingly, genes involved in the cell cycle (such as cyclins) were reduced, in accordance with the GO categories regarding negative regulation of cell cycle and mitotic cell cycle.

Importantly, rtTNF $\alpha$ affected a number of genes involved in proteolysis, tissue remodeling and cytoskeleton (Fig. 6). This set of genes includes matrix metalloproteinase- 2 (MMP-2 or gelatinase A), tissue inhibitor of metallopro- 


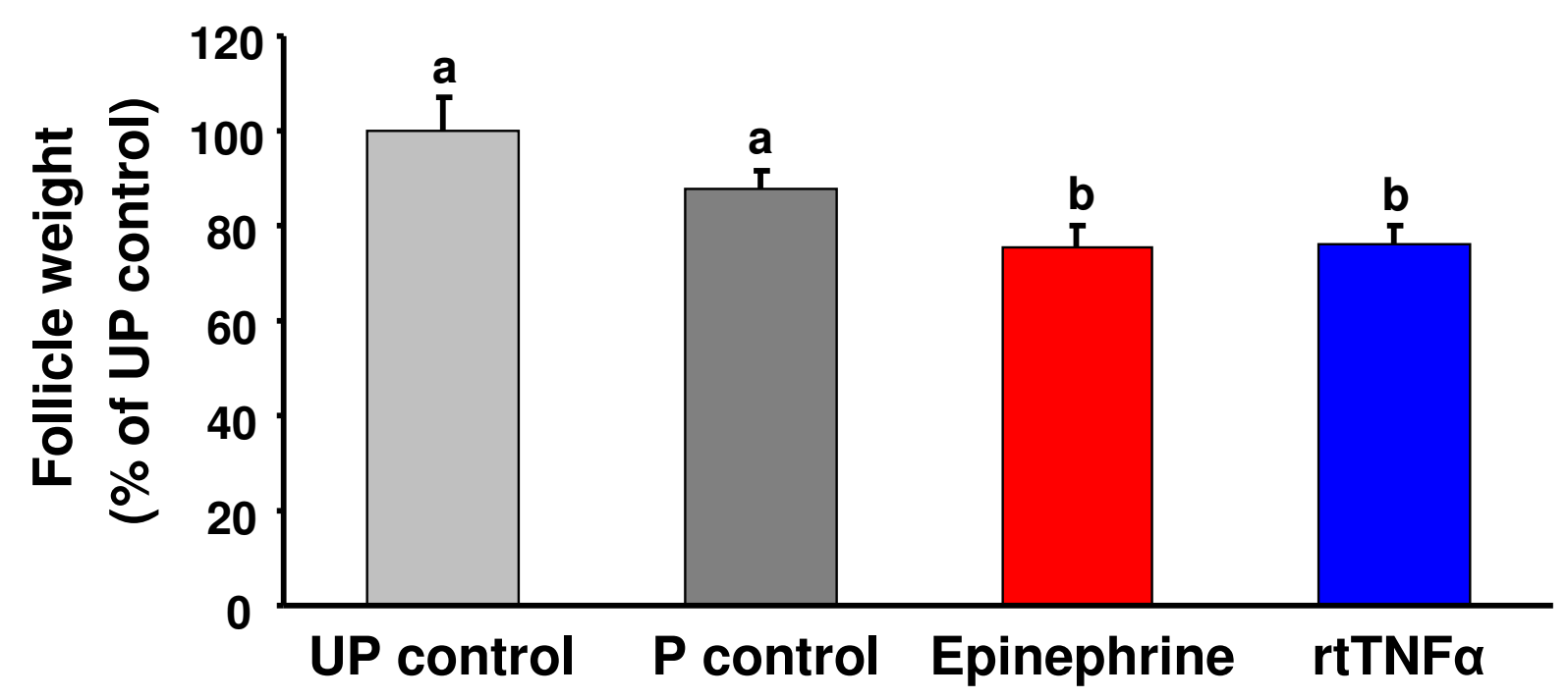

Figure 3 Effects of rtTNFa treatment in vitro on follicle contraction in brown trout preovulatory follicles. Preovulatory brown trout ovarian follicles were incubated for $16 \mathrm{~h}$ at $15^{\circ} \mathrm{C}$ in the presence or absence of the test compounds epinephrine and rtTNFa. Each bar represents the mean \pm SE from three independent experiments, each performed with preovulatory follicles from a different female and assayed in triplicate. The results are expressed as percent change with respect to the unpunctured control group (UP control) which has been set at 100\%. Punctured (P) trout preovulatory ovarian follicles were incubated in the absence or presence of epinephrine $(10 \mu \mathrm{M})$ or rtTNFa $(50 \mathrm{ng} / \mathrm{ml})$. Statistically significant $(p<0.05)$ differences among groups are indicated by different letters.

teinase 2 (TIMP-2), plasminogen precursor-1,

ADAMTS-3 (a disintegrin and metalloproteinase with thrombospondin-like motifs 3), serine proteases (serine protease-like protein-1 and 3), complement components (complement factor $\mathrm{H}-2$, complement factor MASP-3, complement factor $\mathrm{B} / \mathrm{C} 2-\mathrm{B}$, complement component $\mathrm{C} 9$ and complement receptor 1-1), cathepsins (cathepsin D2, C-2, B-2 and Y), cytoskeletal proteins and sarcomeric proteins involved in contractile function (actins, myosins and troponins).

Treatment with rtTNF $\alpha$ also caused an increase in the expression of immune-related genes in the trout ovary (Fig. 6 and Additional File 1, Figure S1). Several cytokines and chemokines, such as the small inducible cytokine B14 precursor (CXCL14), CCL4, leukocyte cell-derived chemotaxin 2 or chemokine-like factor family member 3 were induced. Furthermore, rtTNF $\alpha$ increased the expression of genes involved in communication and signaling, such as several MAP kinases and NF-kappaB inhibitor alpha transcripts ( 1 and 3 ). Also, genes coding for immune-related receptors showed changes in expression, such as chemokine 5 a receptor-like, $\mathrm{C}$ type lectin receptor B and, as indicated above, several TNF receptor superfamily members.

In the present study, we selected eight differentially expressed genes representing varying levels of expression to verify the microarray results by qPCR (Table 2) using the same experimental treatments. Results obtained by
qPCR validated the data obtained from microarray analysis. Genes such as small inducible cytokine B14 precursor, CCL4 and triosephosphate isomerase were highly regulated in the qPCR analysis.

Also, we identified by qPCR (Table 3 ) the expression of genes that have been postulated to be involved in proteolytic and tissue remodeling processes during ovulation in trout (i.e. kallikrein, KT-14; trout ovulatory protein-2, TOP-2; and novel osteopontin-like protein, NOP) [2830]. The expression of this set of genes was significantly $(\mathrm{p}<0.05)$ increased over control in response to rtTNF $\alpha$ treatment $(100 \mathrm{ng} / \mathrm{ml})$. Furthermore, we analyzed two interesting genes that are also expressed during the ovulatory process, such as macrophage migration inhibitory factor (MIF), a cytokine stimulated in response to human chorionic gonadotropin (hCG) or LH in follicular fluid [31], and TNF $\alpha$ trout decoy receptor (TDcR), a soluble receptor detected in the ovary during and after natural ovulation [32] (Table 3). The expression of both genes was significantly $(\mathrm{p}<0.05)$ increased by $\mathrm{rtTNF} \alpha$.

\section{Discussion}

In mammals, it has been hypothesized that TNF $\alpha$ may be a component of the ovulatory mechanism [33,34]. In fact, TNF $\alpha$ is produced in the ovary $[35,36]$ and its role in steroidogenesis, proliferation and follicular apoptosis has been studied in several species [37,38]. Furthermore, ovulation is blocked after injection of TNF $\alpha$ antibodies 
A

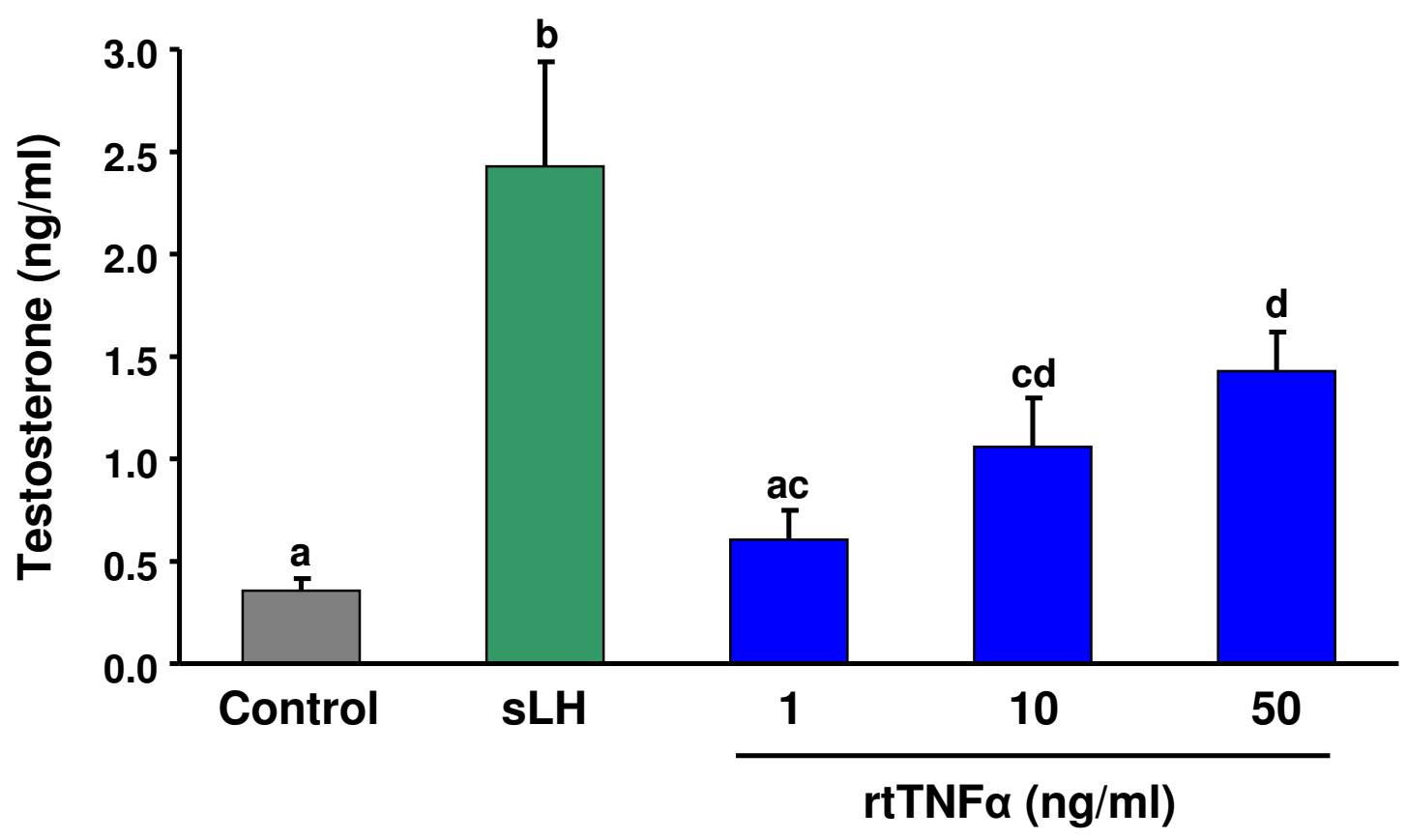

B

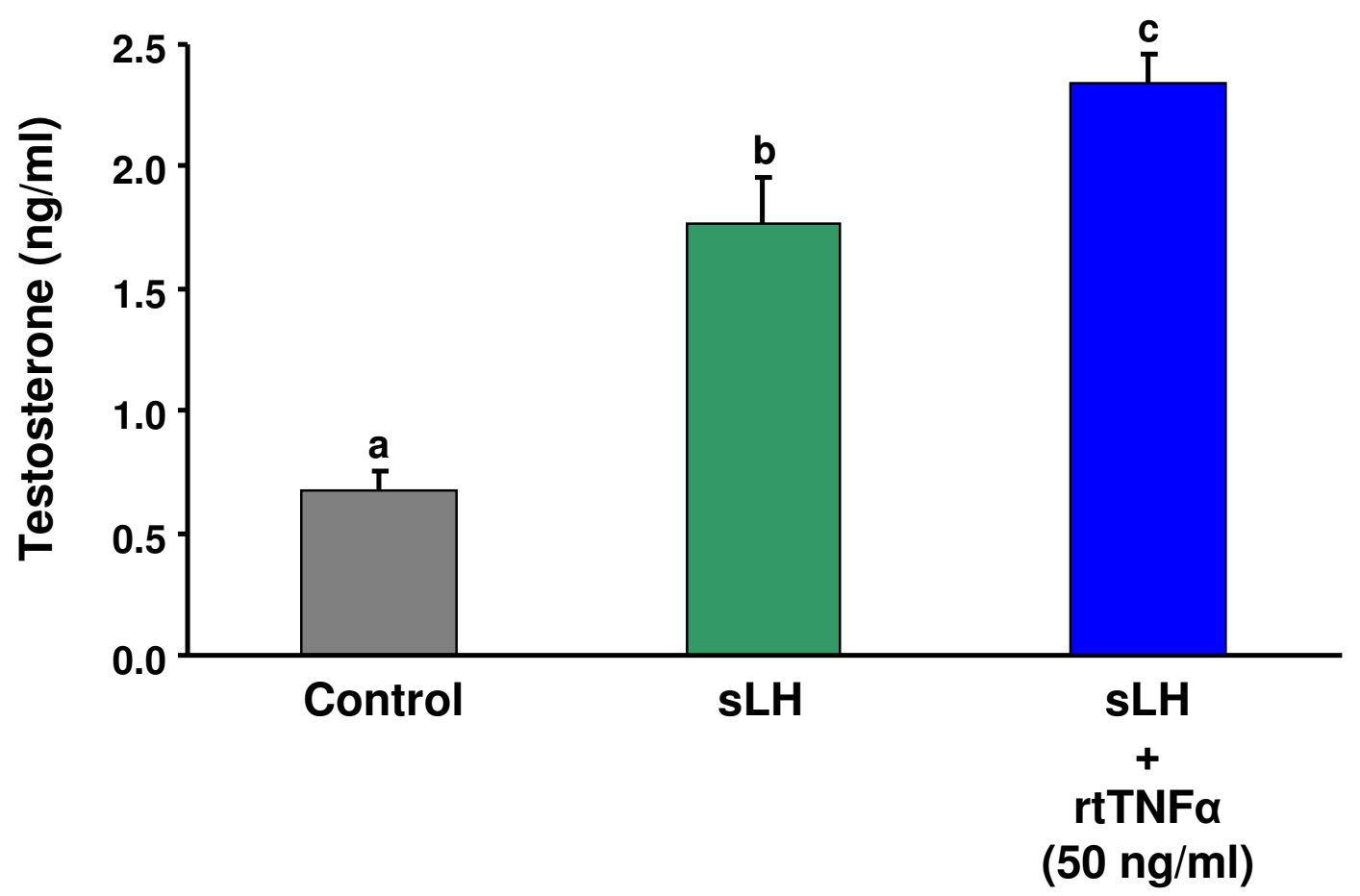

Figure 4 Steroid production of brown trout preovulatory follicles treated with rtTNFa in vitro. Preovulatory trout follicles were incubated in the absence or presence of coho salmon LH (sLH; $25 \mathrm{ng} / \mathrm{ml})$, different concentrations of rtTNFa $(1,10 \mathrm{and} 50 \mathrm{ng} / \mathrm{ml})$ (A) or sLH in the absence or presence of $50 \mathrm{ng} / \mathrm{ml}$ of rtTNFa (B) for $24 \mathrm{~h}$ at $15^{\circ} \mathrm{C}$. Testosterone levels were measured in the medium at the end of the incubation period. Each bar represents the mean \pm SE of two independent experiments, each with ovarian tissue from a separate female and assayed in triplicate. Statistically significant $(p<0.05)$ differences among groups are indicated by different letters. 


\section{$\square>1 \log _{2}$ ER $\square 0.5-1 \log _{2}$ ERD $0-0.5 \log _{2}$ ER}

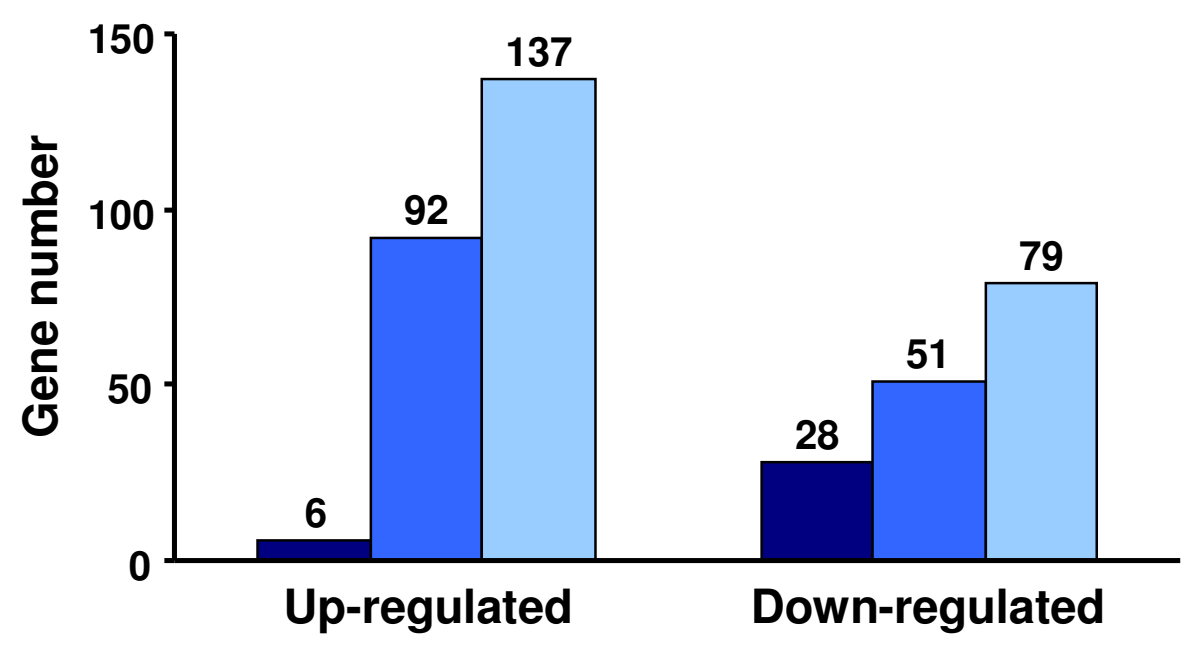

Figure 5 Gene response to in vitro rtTNFa treatment of brown trout preovulatory follicles. Total number of up- and down-regulated genes (> $0 \log _{2}$ expression ratio, ER; $\left.p<0.01\right)$ expressed in response to rtTNFa $(100 \mathrm{ng} / \mathrm{ml})$ treatment as assessed by microarray analysis using the SFA2.0 platform.

into the follicular antrum [8]. All these observations suggest that TNF $\alpha$ plays multiple physiological roles in ovarian function in mammals. In order to study the possible involvement of TNF $\alpha$ in ovarian function in fish, we have investigated for the first time the effects of rtTNF $\alpha$ on ovarian function in a teleost fish, the brown trout (Salmo trutta). In particular, we examined the in vitro effects of rtTNF $\alpha$ treatment on ovarian apoptosis and viability, follicle contraction, steroid production and gene expression. One of the most significant results obtained in the present study is the stimulation of trout granulosa cell apoptosis by rtTNF $\alpha$, as reported in mammals [8], and the modulatory effects of this cytokine on the expression of apoptosis-related genes in trout preovulatory follicles. Interestingly, the pro-apoptotic effects of rtTNF $\alpha$ at the cellular and molecular levels parallel those reported in the ovary of LPS-treated female trout [10]. In fact, the expression of two anti-apoptotic genes (i.e. cdk inhibitor p21 binding protein and telomerase reverse tran-

scriptase) in the preovulatory ovary was similarly downregulated by in vivo administration of LPS and by in vitro treatment with rtTNF $\alpha$. However, rtTNF $\alpha$ treatment also increased the expression of BCL-2 family members such as BCL2/adenovirus $\mathrm{E} 1 \mathrm{~B} 19-\mathrm{kDa}$ protein-interacting protein 2 and BCL2-associated athanogene 1 (BAG1). BCL-2 interacting protein BAG-1 enhances the anti-apoptotic effects of BCL-2 [39] and expression of BCL-2 in mouse oocytes during fetal development suppresses apoptotic cell death [40]. Furthermore, the expression of ferritin heavy chain-1 was also increased by rtTNF $\alpha$ and its upregulation is known to inhibit TNF $\alpha$-induced apoptosis [41]. These results could suggest the existence of a balance between multiple pro-apoptotic (such as cell death protein RIP, growth arrest and DNA-damage inducible GADD45 beta or nuclear protein 1) and anti-apoptotic genes regulated by TNF $\alpha$ around the time of ovulation that could be important in order to exert a tight, and perhaps localized, control of TNF $\alpha$-induced apoptosis in the trout ovary.

In addition to the induction of apoptosis, treatment of trout preovulatory follicles with rtTNF $\alpha$ caused important changes in the expression of genes involved in proteolysis and remodeling of the ECM. In mammals, alterations in the ECM of the follicle wall are an essential part of ovulation. For the oocyte to be released, extensive breakdown of the collagenous tissue of the theca externa and of the granulosa cell basement membrane, as well as dissociation of granulosa cell layers, are required [42]. In fish, there is also evidence for ECM remodeling during ovulation since it has been reported that MMPs with collagenase activity increase in the follicle wall at the time of ovulation in trout $[43,44]$. Furthermore, up-regulation of other candidate genes possibly involved in ovarian proteolysis such as kallikrein (KT-14), a serine protease postulated to regulate oocyte expulsion in trout [30], TOP-2, a serine protease inhibitor $[29,45]$, as well as serine pro- 


\begin{tabular}{|c|c|c|c|c|c|c|}
\hline Clone ID & Clone name & $\log _{2} E R$ & Clone ID & Clone name & $\log _{2} E R$ & \\
\hline & Apoptosis & & & Cell cycle & & \\
\hline CA364711 & Inhibitor of apoptosis protein 3 & -0.88 & CA379787 & Cyclin G1 & -0.68 & \\
\hline BX075059 & Cdk inhibitor p21 binding protein & -0.66 & CX038032 & G1/S-specific cyclin E1 & -1.21 & \\
\hline CA380121 & Telomerase reverse transcriptase & -0.79 & CA383222 & G2/mitotic-specific cyclin B2 & -1.46 & \\
\hline CA356686 & Receptor-interacting serine/threonine-protein kinase 2 & 0.44 & CA365477 & Cyclin-dependent kinase inhibitor p27kip1 & 0.63 & \\
\hline EG898351 & Nuclear protein 1 & 0.34 & & Complement & & \\
\hline CA358820 & Proteinase activated receptor 1 & 0.90 & CA380133 & Complement factor MASP-3 & 1.90 & \\
\hline CF752659 & Ferritin heavy chain-1 & 0.41 & CA363676 & Complement factor B/C2-B & 1.08 & \\
\hline CU071647 & Nuclear matrix protein NMP200 & -0.72 & BX315058 & Complement factor $\mathrm{H}-2$ & 1.06 & \\
\hline CA363935 & $\mathrm{BCL}$ /adenovirus E1B 19-kDa protein-interacting protein 2 & 0.30 & CA383775 & Complement receptor $1-1$ & 0.52 & \\
\hline CA368739 & $\mathrm{BCL} 2$-associated athanogene 1 & 0.30 & CA365362 & Complement component C9 & 0.51 & \\
\hline CA369202 & Growth arrest and DNA-damage-inducible GADD 45 beta & 0.57 & & Proteolysis, tissue remodeling and cytoskeleton & & \\
\hline & TNF-related & & CA373607 & Matrix metalloproteinase-2 & 0.29 & \\
\hline CA376213 & TNF receptor associated factor 1 & 0.58 & CA351691 & Tissue inhibitor of metalloproteinase 2 & 0.38 & \\
\hline CA351440 & TNF decoy receptor & 0.48 & CA376549 & ADAMTS-3 & 0.40 & \\
\hline CA357109 & Tumor necrosis factor receptor & 0.62 & CR943302 & Tolloid-like protein (nephrosin)-1 & 0.76 & \\
\hline CA342573 & Tumor necrosis factor receptor superfamily member $11 \mathrm{~B}$ & 0.78 & CA378743 & Fibronectin precursor & -2.80 & \\
\hline CA354408 & Tumor necrosis factor receptor superfamily member 9 & 0.71 & CU072351 & Plasminogen precursor-1 & 1.08 & \\
\hline & Cytokines and chemokines & & CA366393 & Mannan-binding lectin serine protease $2-1$ & -0.51 & \\
\hline CU068239 & Leukocyte cell-derived chemotaxin 2 & 0.61 & BX079247 & Serine protease-like protein- 3 & 0.35 & \\
\hline CA374135 & CCL4 & 0.71 & CU069718 & Serine protease-like protein-1 & -0.44 & \\
\hline CA368962 & Chemokine-like factor family member 3 & 0.58 & CA365458 & Cathepsin D-2 & 0.53 & \\
\hline CA344136 & Small inducible cytokine B14 precursor & 0.34 & DY721571 & Cathepsin C-2 & -0.31 & \\
\hline CA343117 & CC chemokine SCYA110-2 & -0.38 & CA344488 & Cathepsin B-2 & 0.33 & \\
\hline CA342706 & Chemokine 5 a receptor-like & 0.73 & CA348983 & Cathepsin Y & -0.34 & Expression scale \\
\hline & Kinase cascades & & DW546492 & Hyaluronan and proteoglycan link protein 2 precursor & 1.04 & $>2$ \\
\hline CA354801 & MAPK/ERK kinase kinase 1-1 & 0.47 & CA370834 & Coagulation factor $\mathrm{X}$ precursor & 0.36 & 1 to 2 \\
\hline CA382570 & Mitogen-activated protein kinase 13 & -0.44 & EV382019 & Secretory granule proteoglycan core protein & 0.68 & 0.5 to 1 \\
\hline CA342311 & Tyrosine-protein kinase ZAP-70 & -0.47 & DV199497 & Actin, alpha skeletal 5 & 0.69 & 0 to 0.5 \\
\hline EG927872 & Tyrosine-protein kinase $\mathrm{HCK}$ & -0.47 & CU062860 & Beta actin-2 & 0.62 & 0 to -0.5 \\
\hline CA343143 & NF-kappaB inhibitor alpha-1 & 0.48 & CA039449 & Troponin 1-4, fast skeletal muscle & 0.62 & -0.5 to -1 \\
\hline CA388461 & NF-kappaB inhibitor alpha-3 & 0.53 & EG827615 & Myosin heavy chain, cardiac muscle beta isoform & 0.63 & -1 to -2 \\
\hline CX138691 & Thymidine kinase, cytosolic & -2.25 & DY467707 & Tropomyosin alpha 3 chain- 2 & 0.87 & $<-2$ \\
\hline
\end{tabular}

Figure 6 Genes differentially regulated by rtTNFa in brown trout preovulatory follicles. Brown trout preovulatory follicles incubated in the absence or presence of rtTNFa $(100 \mathrm{ng} / \mathrm{ml})$ were used for gene expression analysis using the SFA2.0 microarray. Data shown represent mean log ${ }_{2}$ ER (expression ratio). Significantly up- and down-regulated genes ( $p<0.01$, Student's t-test, 12 spot replicates per gene) are highlighted with color scale. See Additional File 1, Figure S1 for complete microarray data.

tease 23 and ADAM22, two genes identified by microarray analysis [46], occurs during natural ovulation in trout. In medaka (Oryzias latipes), several MMPs and TIMP-2 have been shown to play a crucial role in ECM remodeling, degradation of the follicle wall and, subsequently, ovulation, as in mammals [47]. Specifically, MMP-2 (gelatinase A) and membrane-type 2 MMP facilitate follicle rupture during ovulation by degrading type IV and type I collagen, respectively, and TIMP-2 regulates the production and activity of MMP-2 in medaka preovulatory follicles [47]. However, there is no evidence to date regarding the nature of the regulatory factors that control the production and activity of proteins involved in follicle rupture and ovulation in fish. In the present study we show that rtTNF $\alpha$ induces the expression of proteolytic enzymes in the trout ovary that belong to the three classes of proteinases known to be involved in ECM remodeling during ovulation in mammals: MMPs (e.g. MMP-2), plasmin/plasminogen activator system (e.g. plasminogen precursor-1) and ADAMTS (e.g.

ADAMTS-3). In addition to these proteinases, $r \mathrm{TNF} \alpha$ induced the expression of TOP-2, TIMP-2, kallikrein and other serine proteases. Furthermore, we observed an increase in the expression of several cathepsins (D-2, C-2, $\mathrm{B}-2$ and $\mathrm{Y}$ ) in agreement with recent information suggest- ing an important role for cathepsins during ovarian follicle growth and maturation in fish [48]. Therefore, we have evidence supporting the hypothesis that rtTN $\alpha$ may be an important factor regulating the degradation of the follicle wall, as a prerequisite for oocyte release, in the trout ovary.

Here we also provide direct evidence for a stimulatory role of rtTNF $\alpha$ on follicle contraction, a process required for oocyte expulsion during ovulation. Increased follicle contraction is most likely related to the observed up-regulation of the expression of cytoskeletal and sarcomeric proteins involved in contractile function. In a previous study we suggested that the stimulation of trout follicle contraction by conditioned medium from LPS-stimulated trout macrophages was due to the presence of inflammatory cytokines in the medium [10]. We have recently confirmed the ability of LPS-stimulated trout macrophages to secrete native TNF $\alpha$ protein [13] and, consequently, we can reasonably speculate that TNF $\alpha$ was at least one of the cytokines present in conditioned medium responsible for the stimulation of follicle contraction. In addition to TNF $\alpha$, other factors such as chatecholamines and prostaglandins stimulate follicle contraction in trout $[15,16]$. Future studies in our laboratory are devoted to investigate a possible link between 


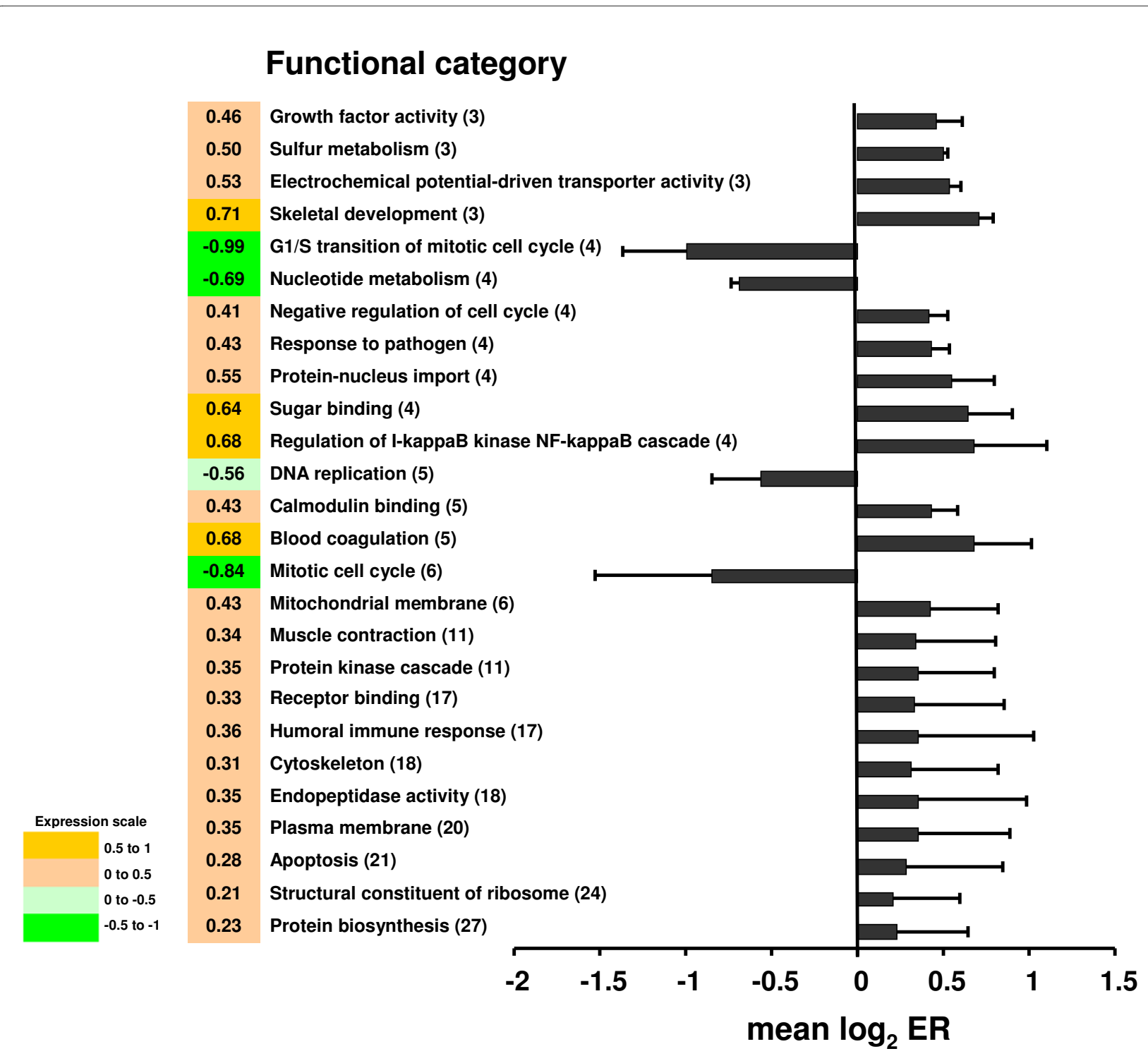

Figure 7 Gene Ontology analysis of genes expressed in response to rtTNFa treatment in brown trout preovulatory follicles. Differentially expressed genes were grouped by Gene Ontology functional categories and mean $\log _{2}$ ER (expression ratio) was analyzed by Student's t-test ( $p<0.05$ ). The number of regulated genes for each category is shown in parenthesis. Data is shown as mean $\log _{2} E R \pm S E$. The expression value is coded with color scale. See Additional File 2, Figure S2A and B for the complete microarray data.

TNF $\alpha$ and prostaglandins in the stimulation of follicle contraction in trout preovulatory follicles.

The stimulation of testosterone production by rtTNF $\alpha$ in trout preovulatory follicles is interesting in relation to the known potentiatory role of androgens in the ovulatory process in mammals [49]. Although the precise mechanism by which androgens may induce ovulation in mammals is not well characterized, there is evidence for the increased expression of proteolytic enzymes such as kallikrein [30], suggesting that androgens could be involved in follicle rupture. In female salmonid fish (salmon and trout), testosterone plasma levels are known to increase significantly prior to ovulation $[30,50]$ but there is no functional evidence for a role of testosterone in ovulation in fish. Our results, supported by the fact that ovarian follicles from LPS-treated trout showed increased sLHstimulated testosterone production [10], suggest that TNF $\alpha$ could be responsible, at least in part, for the high ovarian testosterone output in preovulatory trout. It is tempting to speculate that TNF $\alpha$-induced testosterone could play a role in the ovulatory process in fish.

Based on our observations on the stimulatory effects of rtTNF $\alpha$ on trout granulosa cell apoptosis and on the expression of genes involved in proteolysis of the trout 
Table 2: qPCR validation of microarray results for selected genes

\begin{tabular}{|c|c|c|c|c|}
\hline Clone ID & Clone name & Regulation & Microarray & qPCR \\
\hline CA344136 & $\begin{array}{l}\text { Small inducible } \\
\text { cytokine B14 precursor }\end{array}$ & Up-regulated & 0.33 & 1.33 \\
\hline CU068239 & $\begin{array}{l}\text { Leukocyte cell-derived } \\
\text { chemotaxin } 2\end{array}$ & Up-regulated & 0.61 & 0.41 \\
\hline CA374135 & CCL4 & Up-regulated & 0.70 & 2.36 \\
\hline CA351440 & TNF decoy receptor & Up-regulated & 0.49 & 0.38 \\
\hline DW550559 & Coronin-1C & Down-regulated & -1.18 & -0.24 \\
\hline CU067298 & $\begin{array}{l}\text { Triosephosphate } \\
\text { isomerase }\end{array}$ & Down-regulated & -1.28 & -2.47 \\
\hline CU069718 & $\begin{array}{l}\text { Serine protease-like } \\
\text { protein-1 }\end{array}$ & Down-regulated & -0.43 & -0.68 \\
\hline CA364711 & $\begin{array}{l}\text { Inhibitor of apoptosis } \\
\text { protein } 3\end{array}$ & Down-regulated & -0.88 & -1.24 \\
\hline
\end{tabular}

follicle wall, we suggest that, as described in mammals (reviewed in [42]), TNF $\alpha$ in trout could facilitate ovulation by serving the dual role of promoting collagen degradation in the follicle wall and further disrupting it by deleting follicular cells by apoptosis. This role of TNF $\alpha$, coupled with its ability to directly stimulate follicle contraction in trout preovulatory follicles, strongly suggests that TNF $\alpha$ may have pro-ovulatory actions in fish. In support of the proposed role for TNF $\alpha$ in the ovulatory process in fish, inhibition of the activity of TNF $\alpha$-converting enzyme (TACE/ADAM17), which inhibits TNF $\alpha$ secretion by trout macrophages [13], blocks ovulation in isolated medaka follicles [47]. Furthermore, we have recently shown that LPS administration in vivo may result in an advancement of the time of ovulation in trout [51]. Having demonstrated that LPS administration in vivo induces the expression of TNF $\alpha$ in the trout ovary (this study), we can speculate that ovarian production of TNF $\alpha$ may trigger the ovulatory process. At least in trout, the expression of ligands and receptors of the TNF family, most notably TNF $\alpha$ itself [52] and TDcR [32], which may serve to bind TNF $\alpha$ and control its activity, increase at the time of ovulation.

\section{Conclusions}

This is the first report in fish describing the possible role of TNF $\alpha$ in trout ovarian follicles during the preovulatory period. rtTNFo induced apoptosis in trout granulosa cells and altered the expression of genes known to be involved in the normal ovulatory process in trout, including genes involved in inflammation, proteolysis and tissue remodeling. Furthermore, rtTNF $\alpha$ stimulated the contraction of preovulatory trout follicles as well as the production of testosterone. These results suggest that TNF $\alpha$, as in

Table 3: In vitro effects of $\mathrm{rtTNFa}(100 \mathrm{ng} / \mathrm{ml})$ on candidate gene expression in brown trout preovulatory follicles

\begin{tabular}{|c|c|c|}
\hline GenBank accession & Gene name & qPCR \\
\hline AF005026 & Kallikrein (KT-14) & $1.01 *$ \\
\hline$\underline{\text { AF223388 }}$ & Novel osteopontin-like protein (NOP) & $0.85 *$ \\
\hline$\underline{\text { U67854 }}$ & Trout ovulatory protein-2 (TOP-2) & $0.60 *$ \\
\hline AF156738 & Trout decoy receptor (TDcR) & $1.14 *$ \\
\hline$\underline{\mathrm{CA} 380218}$ & $\begin{array}{l}\text { Macrophage migration inhibitory factor } \\
\text { (MIF) }\end{array}$ & $1.17^{*}$ \\
\hline
\end{tabular}

The relative expression was determined by real-time PCR (qPCR) and normalized to the abundance of $18 \mathrm{~S}$. The results from follicles from 3 separate females are expressed as mean - $\quad \mathrm{Ct}(\mathrm{n}=3)$ with respect to the control, which has been set at 0 for each particular gene. Statistically significant $(p<0.05)$ differences with respect to the control group are indicated by an asterisk $(*)$. Genes are: kallikrein (KT-14), NOP (novel osteopontin-like protein), TOP-2 (trout ovulatory protein-2), TDcR (trout decoy receptor), MIF (macrophage migration inhibitory factor). 
mammals, may be an important factor in the control of ovulation in fish by participating in the biomechanics of follicle weakening and rupture as well as in oocyte expulsion during ovulation. Furthermore, the results of the present study support the idea that bacterial pathogens, through the induction of pro-inflammatory cytokines such as TNF $\alpha$, could have an impact on ovarian function, possibly resulting in an advancement of ovulation in fish, with important consequences for broodstock and egg quality in farmed fish.

\section{Additional material}

\section{Additional file 1 Supplemental figure 1: Complete list of differentially} expressed genes.

Additional file 2 Supplemental figure 2 A and B: Complete Gene Ontology analysis.

\section{Competing interests}

The authors declare that they have no competing interests.

\section{Authors' contributions}

DC performed gene expression analyses, testosterone measurement, follicle contraction determinations and the writing of the manuscript. EB participated in the generation of the apoptosis and cell viability data. NR carried out the generation of recombinant TNFa. SM participated in the design of the study. AK participated in the microarray analysis. FWG participated in the design of the study and in the execution of the LPS experiment. JB participated in the design of the study, in execution of the experiments and in the writing of the manuscript. JVP coordinated and participated in the design of the study as well as in the execution of the experiments and drafted the manuscript. All authors read and approved the final manuscript.

\section{Acknowledgements}

We would like to thank Mr Antonino Clemente at the Piscifactoria de Bagà (Departament de Medi Natural, Generalitat de Catalunya, Spain) for providing the fish used in this study, and for his generous assistance. We would also like to thank the Turku Centre of Biotechnology for the preparation of microarrays and Dr Arjan Palstra for comments on the manuscript. This study was funded in part by grants from the Ministerio de Ciencia e Innovación (Acción Integrada HF2005-0030 and AGL2009-07006), Spain to JVP and from Egide, France to JB.

\section{Author Details}

'Departament de Fisiologia, Facultat de Biologia, Universitat de Barcelona and Institut de Biomedicina de la Universitat de Barcelona (IBUB), 08028 Barcelona, Spain, 2Institut National de la Recherche Agronomique (INRA), UR1037 SCRIBE, IFR140, Campus de Beaulieu, F-35000 Rennes, France, ${ }^{3}$ Unitat de Fisiologia Animal, Departament de Biologia Cellular, Fisiologia i d'Immunologia, Facultat de Ciències, Universitat Autònoma de Barcelona (UAB), Spain, ${ }^{4}$ Nofima Akvaforsk Fiskeriforskning AS, PO Box 5010, Ås NO-1430, Norway and ${ }^{5}$ Great Lakes Water Institute, University of Wisconsin-Milwaukee, Wisconsin, USA

Received: 15 February 2010 Accepted: 12 April 2010

Published: 12 April 2010

\section{References}

1. Currie JL, Woo PTK: Effects of the pathogenic haemoflagellate, Cryptobia salmositica on brood fish, Oncorhynchus mykiss. Environ Biol Fish 2008, 83(3):355-365.

2. Schreck CB, Contreras-Sanchez W, Fitzpatrick MS: Effects of stress on fish reproduction, gamete quality, and progeny. Aquaculture 2001, 197(14):3-24.

3. Goetz FW, lliev DB, McCauley LA, Liarte CQ, Tort LB, Planas JV, MacKenzie $S$ : Analysis of genes isolated from lipopolysaccharide-stimulated rainbow trout (Oncorhynchus mykiss) macrophages. Mol Immunol 2004, 41(12):1199-1210.
4. MacKenzie S, Planas JV, Goetz FW: LPS-stimulated expression of a tumor necrosis factor-alpha mRNA in primary trout monocytes and in vitro differentiated macrophages. Dev Comp Immunol 2003, 27(5):393-400.

5. Calleja-Agius J, Muttukrishna S, Jauniaux E: Role of TNF-a in human female reproduction. Expert Rev Endocrinol Metab 2009, 4:273-282.

6. Amsterdam A, Keren-Tal I, Aharoni D, Dantes A, Land-Bracha A, Rimon E, Sasson R, Hirsh L: Steroidogenesis and apoptosis in the mammalian ovary. Steroids 2003, 68(10-13):861-867.

7. Roby KF, Terranova PF: Effects of tumor necrosis factor-alpha in vitro on steroidogenesis of healthy and atretic follicles of the rat: theca as a target. Endocrinology 1990, 126(5):2711-2718.

8. Murdoch WJ, Colgin DC, Ellis JA: Role of tumor necrosis factor-alpha in the ovulatory mechanism of ewes. J Anim Science 1997, 75(6):1601-1605.

9. Murdoch WJ, Lund SA: Prostaglandin-independent anovulatory mechanism of indomethacin action: inhibition of tumor necrosis factor alpha-induced sheep ovarian cell apoptosis. Biol Reprod 1999, 61(6):1655-1659.

10. MacKenzie S, Montserrat N, Mas M, Acerete L, Tort L, Krasnov A, Goetz FW, Planas JV: Bacterial lipopolysaccharide induces apoptosis in the trout ovary. Reprod Biol Endocrinol 2006, 4:46.

11. Goetz FW, Bergman HL: The effects of steroids on final maturation and ovulation of oocytes from brook trout (Salvelinus fontinalis) and yellow perch (Perca flavescens). Biol Reprod 1978, 18(2):293-298

12. Swanson P, Suzuki K, Kawauchi H, Dickhoff WW: Isolation and characterization of two coho salmon gonadotropins, GTH I and GTH II. Biol Reprod 1991, 44(1):29-38.

13. Roher N, Callol A, Planas JV, Goetz FW, MacKenzie SA: Endotoxin recognition in fish results in inflammatory cytokine secretion not gene expression. Innate Immun 2010 in press

14. Planas JV, Goetz FW, Swanson P: Stimulation of brook trout ovarian steroidogenesis by gonadotropins I and II is mediated by the cyclic adenosine 3',5'-monophosphate/protein kinase A pathway. Biol Reprod 1997, 57(3):647-654.

15. Goetz FW, Bradley JA: Stimulation of in vitro ovulation and contraction of brook trout (Salvelinus fontinalis) follicles by adrenaline through alpha-adrenoreceptors. J Reprod Fertil 1994, 100(2):381-385.

16. Hsu SY, Goetz FW: The effects of $E$ and F prostaglandins on ovarian CAMP production and follicular contraction in the brook trout (Salvelinus fontinalis). Gen Comp Endocrinol 1992, 88(3):434-443.

17. Méndez E, Mæland M, Skålhegg BS, Planas JV: Activation of the CAMPdependent protein kinase signaling pathway by luteinizing hormone in trout theca layers. Mol Cell Endocrinol 2003, 205(1-2):11-20.

18. Montserrat N, González A, Méndez E, Piferrer F, Planas JV: Effects of follicle stimulating hormone on estradiol-17[beta] production and P-450 aromatase (CYP19) activity and mRNA expression in brown trout vitellogenic ovarian follicles in vitro. Gen Comp Endocrinol 2004, 137(2):123-131

19. Koskinen H, Pehkonen P, Vehniäinen E, Krasnov A, Rexroad C, Afanasyev S, Mölsa H, Oikari A: Response of rainbow trout transcriptome to model chemical contaminants. Biochem Biophys Res Commun 2004 320(3): $745-753$

20. Krasnov A, Koskinen H, Pehkonen P, Rexroad CE, Afanasyev S, Molsa H: Gene expression in the brain and kidney of rainbow trout in response to handling stress. BMC Genomics 2005, 6(1):3.

21. Ashburner M, Ball CA, Blake JA, Botstein D, Butler H, Cherry JM, Davis AP, Dolinski K, Dwight SS, Eppig JT, Harris MA, Hill DP, Issel-Tarver L, Kasarskis A, Lewis S, Matese JC, Richardson JE, Ringwald M, Rubin GM, Sherlock G: Gene ontology: tool for the unification of biology. The Gene Ontology Consortium. Nat Genet 2000, 25(1):25-29.

22. Livak KJ, Schmittgen TD: Analysis of Relative Gene Expression Data Using Real-Time Quantitative PCR and the 2(-Delta DeltaC(T)) Method. Methods 2001, 25(4):402-408.

23. MacKenzie S, Balasch JC, Novoa B, Ribas L, Roher N, Krasnov A, Figueras A: Comparative analysis of the acute response of the trout, O. mykiss, head kidney to in vivo challenge with virulent and attenuated infectious hematopoietic necrosis virus and LPS-induced inflammation. BMC Genomics 2008, 9:141.

24. MacKenzie S, Iliev D, Liarte C, Koskinen H, Planas JV, Goetz FW, Molsa H, Krasnov A, Tort L: Transcriptional analysis of LPS-stimulated activation of trout (Oncorhynchus mykiss) monocyte/macrophage cells in primary culture treated with cortisol. Mol Immunol 2006, 43(9):1340-1348. 
25. Djordjevic B, Skugor S, Jorgensen SM, Overland M, Mydland LT, Krasnov A: Modulation of splenic immune responses to bacterial lipopolysaccharide in rainbow trout (Oncorhynchus mykiss) fed lentinan, a beta-glucan from mushroom Lentinula edodes. Fish Shellfish Immunol 2009, 26(2):201-209.

26. Mahajan KN, Mitchell BS: Role of human Pso4 in mammalian DNA repair and association with terminal deoxynucleotidyl transferase. Proc Natl Acad Sci 2003, 100(19):10746-10751.

27. Massard C, Zermati Y, Pauleau AL, Larochette N, Metivier D, Sabatier L, Kroemer G, Soria JC: hTERT: a novel endogenous inhibitor of the mitochondrial cell death pathway. Oncogene 2006, 25(33):4505-4514

28. Bobe J, Goetz FW: A novel osteopontin-like protein is expressed in the trout ovary during ovulation. FEBS Lett 2001, 489(2-3):119-124.

29. Garczynski MA, Goetz FW: Molecular characterization of a ribonucleic acid transcript that is highly up-regulated at the time of ovulation in the brook trout (Salvelinus fontinalis) ovary. Biol Reprod 1997, 57(4):856-864.

30. Hajnik CA, Goetz FW, Hsu SY, Sokal N: Characterization of a ribonucleic acid transcript from the brook trout (Salvelinus fontinalis) ovary with structural similarities to mammalian adipsin/complement factor D and tissue kallikrein, and the effects of kallikrein-like serine proteases on follicle contraction. Biol Reprod 1998, 58(4):887-897.

31. Wada S, Kudo T, Kudo M, Sakuragi N, Hareyama H, Nishihira J, Fujimoto S: Induction of macrophage migration inhibitory factor in human ovary by human chorionic gonadotrophin. Hum Reprod 1999, 14(2):395-399.

32. Bobe J, Goetz FW: A tumor necrosis factor decoy receptor homologue is up-regulated in the brook trout (Salvelinus fontinalis) ovary at the completion of ovulation. Biol Reprod 2000, 62(2):420-426.

33. Murdoch WJ, Van Kirk EA, Murdoch J: Plasmin cleaves tumor necrosis factor alpha exodomain from sheep follicular endothelium: implication in the ovulatory process. Biol Reprod 1999, 60(5):1166-1171.

34. Terranova PF: Potential roles of tumor necrosis factor-alpha in follicular development, ovulation, and the life span of the corpus luteum. Domest Anim Endocrinol 1997, 14(1):1-15.

35. Loret de Mola JR, Goldfarb JM, Hecht BR, Baumgardner GP, Babbo CJ, Friedlander MA: Gonadotropins induce the release of interleukin-1 beta, interleukin- 6 and tumor necrosis factor-alpha from the human preovulatory follicle. Am J Reprod Immunol 1998, 39(6):387-390.

36. Zolti M, Meirom R, Shemesh M, Wollach D, Mashiach S, Shore L, Rafael ZB: Granulosa cells as a source and target organ for tumor necrosis factoralpha. FEBS Lett 1990, 261(2):253-255.

37. Okuda K, Sakumoto R: Multiple roles of TNF super family members in corpus luteum function. Reprod Biol Endocrinol 2003, 1:95.

38. Terranova PF, Rice VM: Review: cytokine involvement in ovarian processes. Am J Reprod Immunol 1997, 37(1):50-63.

39. Wang HG, Takayama S, Rapp UR, Reed JC: BCl-2 interacting protein, BAG1, binds to and activates the kinase Raf-1. Proc Natl Acad Sci 1996, 93(14):7063-7068.

40. Flaws JA, Hirshfield AN, Hewitt JA, Babus JK, Furth PA: Effect of bcl-2 on the primordial follicle endowment in the mouse ovary. Biol Reprod 2001, 64(4):1153-1159.

41. Pham CG, Bubici C, Zazzeroni F, Papa S, Jones J, Alvarez K, Jayawardena S, De Smaele E, Cong R, Beaumont C, Torti FM, Torti SV, Franzoso G: Ferritin heavy chain upregulation by NF-kappaB inhibits TNFalpha-induced apoptosis by suppressing reactive oxygen species. Cell 2004, 119(4):529-542

42. Curry TE Jr, Smith MF: Impact of extracellular matrix remodeling on ovulation and the folliculo-luteal transition. Semin Reprod Med 2006 24(4):228-241.

43. Berndtson AK, Goetz FW: Protease activity in brook trout (Salvelinus fontinalis) follicle walls demonstrated by substrate-polyacrylamide gel electrophoresis. Biol Reprod 1988, 38(2):511-516.

44. Berndtson AK, Goetz FW: Metallo-protease activity increases prior to ovulation in brook trout (Salvelinus fontinalis) and yellow perch (Perca flavescens) follicle walls. Biol Reprod 1990, 42(2):391-398.

45. Coffman MA, Pinter JH, Goetz FW: Trout ovulatory proteins: site of synthesis, regulation, and possible biological function. Biol Reprod 2000, 62(4):928-938.

46. Bobe J, Montfort J, Nguyen T, Fostier A: Identification of new participants in the rainbow trout (Oncorhynchus mykiss) oocyte maturation and ovulation processes using cDNA microarrays. Reprod Biol Endocrinol 2006, 4:39.
47. Ogiwara K, Takano N, Shinohara M, Murakami M, Takahashi T: Gelatinase $A$ and membrane-type matrix metalloproteinases 1 and 2 are responsible for follicle rupture during ovulation in the medaka. Proc Natl Acad Sci 2005, 102(24):8442-8447.

48. Carnevali O, Cionna C, Tosti L, Lubzens E, Maradonna F: Role of cathepsins in ovarian follicle growth and maturation. Gen Comp Endocrino/ 2006, 146(3):195-203.

49. Walters KA, Allan CM, Handelsman DJ: Androgen actions and the ovary. Biol Reprod 2008, 78(3):380-389.

50. Fitzpatrick MS, Kraak G Van der, Schreck CB: Profiles of plasma sex steroids and gonadotropin in coho salmon, Oncorhynchus kisutch, during final maturation. Gen Comp Endocrinol 1986, 62(3):437-451.

51. Crespo D, Planas JV, Bobe J: Lipopolysaccharide administration in preovulatory rainbow trout (Oncorhynchus mykiss) reduces egg quality. Aquaculture 2010, 300(1-4):240-242.

52. Bobe J, Goetz FW: Molecular cloning and expression of a TNF receptor and two TNF ligands in the fish ovary. Comp Biochem Physiol 2001 129(2-3):475-481.

doi: $10.1186 / 1477-7827-8-34$

Cite this article as: Crespo et al., Cellular and molecular evidence for a role of tumor necrosis factor alpha in the ovulatory mechanism of trout Reproductive Biology and Endocrinology 2010, 8:34

\section{Submit your next manuscript to BioMed Centra and take full advantage of:}

- Convenient online submission

- Thorough peer review

- No space constraints or color figure charges

- Immediate publication on acceptance

- Inclusion in PubMed, CAS, Scopus and Google Scholar

- Research which is freely available for redistribution

Submit your manuscript at www.biomedcentral.com/submit
C) Biomed Central 